\title{
EVALUATION OF ARIDITY INDEX IN THE CZECH REPUBLIC WITHIN 1961-2015
}

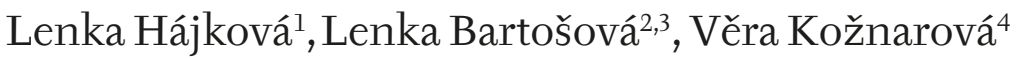

\begin{abstract}
${ }^{1}$ Czech Hydrometeorological Institute, Department of Biometeorological Applications, Na Sabatce 17, Praha, Czech Republic

${ }^{2}$ Mendel University, Faculty of AgriSciences, Department of Agrosystems and Bioclimatology, Zemedelska 1, Brno, Czech Republic

${ }^{3}$ Global Change Research Institute CAS, Belidla 986/4a, Brno, Czech Republic

${ }^{4}$ Czech University of Life Sciences, Faculty of Agrobiology, Food and Natural Resources, Kamycka 129, Praha, Czech Republic
\end{abstract}

To cite this article: HÁJKOVÁ LENKA, BARTOŠOVÁ LENKA, KOŽNAROVÁ VĚRA. 2018. Evaluation of Aridity Index in the Czech Republic within 1961-2015. Acta Universitatis Agriculturae et Silviculturae Mendelianae Brunensis, 66(5): 1111-1118.

To link to this article: https://doi.org/10.11118/actaun201866051111

\begin{abstract}
Drought (similarly as flooding) is considerably the gravest agrometeorological extreme connected with climate change and bringing the highest losses in an agricultural production. The objective of this paper is to study the spatial and temporal variability of the Aridity Index (AI) in the Czech Republic, per decade, during the 55-year period (1961-2015). AI is a climatic index, which is important for recording of the drought phenomenon evolution. The climatic data used, include monthly precipitation totals and air temperature from 120 meteorological stations operated by the Czech Hydrometeorological Institute. The potential evapotranspiration was calculated based on the modified algorithm Penman-Monteith. The data processing was done by the statistical tools of Microsoft Excel and the Geographical Information Systems (Clidata GIS, ArcGIS 10). The results of the analysis showed, that during the decade 1961-1970, almost the whole area of the Czech Republic is classified as "wet" with AI values ranging above 0.60, but over the next years (1971-2015), areas of the south Moravia (e.g. Dyjsko-svratecký ravine, Valticko-lednický area, surroundings of Brno city), and also Prague city and Poohří river basin shifted gradually to "sub-humid" climate zone with AI $<=0.60$. Especially, during the pre-last decade of the study period 1991-2000.
\end{abstract}

Keywords: Aridity Index, precipitation, drought, potential evapotranspiration, temperature, Czech Republic

\section{INTRODUCTION}

The drought phenomenon is refered as the most complex and least understood of all natural hazards, affecting more people than have been affected by any other extreme events (Wilhite, 2000). It is a natural, casual and temporary state of continuous decline in precipitation and water availability in relation to normal values. Too little rainfall, too much rainfall as well cause human adaptation problems. It is defined as meteorological, hydrological and agricultural drought. It is a local phenomenon that is characterized by three parameters: the intensity, duration and extent (Rossi et al., 1992). Drought can be also defined as a negative deviation from the climatic water balance in a specific area over a given time interval (Brázdil, Trnka et al., 2015). For drought analysis are have been using many drought indices e.g. Standardized Precipitation Index (SPI), the Palmer Drought Severity Index (PDSI) and the Palmer Z-index (Z-index). Precipitation and 
temperature are the major weather variables that determine the variability of plant development and crop yields. Drought indices are indispensible tools to detect, monitor, and evaluate drought events. Droughts are common throughout the globe with a devastating damage potential on agriculture, economy, and society in many parts of the world. New drought indices from different disciplines and derived from different data sources were reviewed (Niemeyer, 2008). Even though, the Czech Republic is not generally characterized as a drought-prone region of Europe, drought (and flooding) still occurs (Brázdil et al., 2005, 2007) and is one of the most important climatic extremes in terms of economic damage. This is demonstrated by the examples of severe droughts recorded in 1935, 1976 and especially in 1947 (Možný, 2004). The Aridity Index (AI) is a climatic index, which is useful for recording the evolution of the drought phenomenon. For a given region, the annual mean evapotranspiration (E) and runoff (R) rates are governed primarily by the amount of available energy (the demand) and precipitation (P) (the supply). If the available energy and potential evaporation rates are fairly low, then for a given amount of precipitation runoff is likely to exceed evapotranspiration (Arora, 2002).

The aims of this paper were to: (1) determine AI for the region of the Czech Republic during the period 1961-2015; (2) evaluate AI for particular regions of the Czech Republic.

\section{MATERIALS AND METHODS}

Annual and seasonal precipitation series and annual Aridity Index series of the Czech Republic were investigated with respect to spatial and temporal variations for the period 1961-2015. In the process, the mean annual values for each decade (1961-1970, 2001-2010) were also calculated. In order to calculate Aridity Index (AI), the potential evapotranspiration (PET) is required - the potential evapotranspiration from grassland was calculated based on the modified algorithm Penman-Monteith (Allen et al., 1998).

Then, the Aridity Index is given by:

$\mathrm{AI}=\mathrm{P}_{\mathrm{i}} / \mathrm{PET}_{\mathrm{i}}$

where $\mathrm{P}$ is the monthly precipitation and PET the monthly evapotranspiration (calculated value $=$ $=$ maximum evaporation for a saturated surface).

The evaluation of basic balance of precipitation and potential evapotranspiration from grassland within period 1961-2015 was processed based on CHMI climatological stations (climatological database CLIDATA). The results were calculated both for the whole year, and especially for the growing period (April-September). For the calculation were used daily precipitation totals (so-called „technical" series) from 120 CHMI climatological stations and potential evapotranspiration in daily step. For the data processing of "technical" series, the software packages AnClim (Štěpánek, 2010a), LoadData and ProClimDB (Štěpánek, 2010b) were used. Both software offer complex solution, from tools for handling databases, through data quality control to homogenization of time series, as well as time series analyses, extreme value evaluation and model output verification. The geographical distribution of the meteorological stations is shown in Fig. 1.

Specifically, the processing of climatic data was done by using the Geographical Information Systems (Clidata-GIS, ArcGIS 10.0) - Clidata-DEM method (this method is based on local linear regression between the measured value and digital model relief), and statistical calculations were done by tools of Microsoft Excel.

\section{RESULTS AND DISCUSSION}

The spatial distribution of AI per decade for the period 1961-2010 is shown in Fig. 2, 3, 4, 5

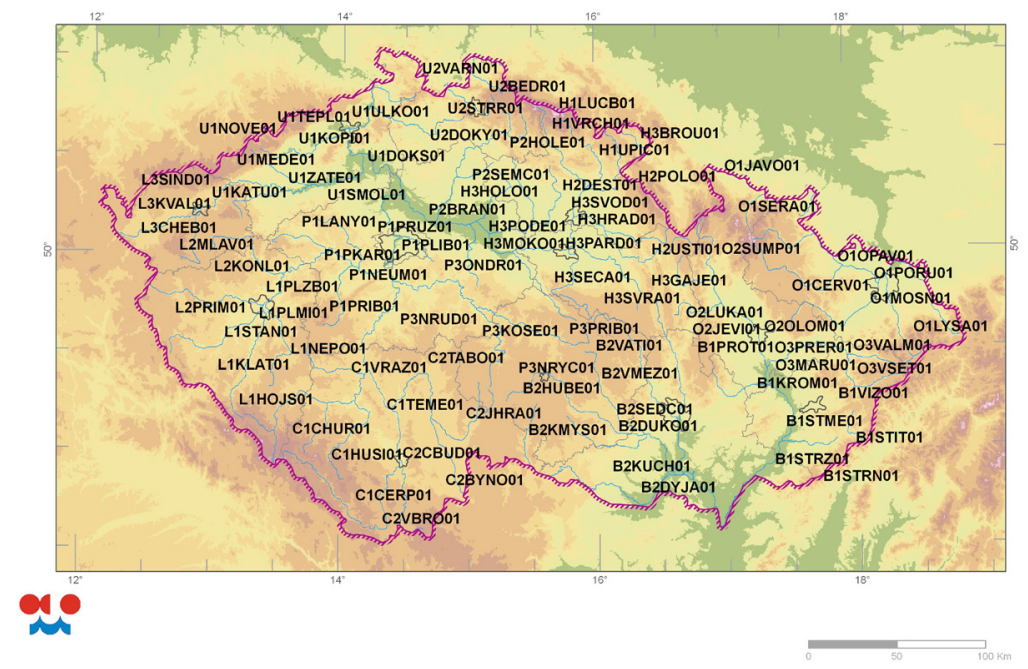

1: Distribution of (used) CHMI stations. 
I: Classification limits of the Aridity Index by Nastos et al. (2013) and evaluation of Aridity Index by the Czech Ministry of Agriculture (the fourth column)

\begin{tabular}{lcccc}
\hline \multicolumn{1}{c}{ Climatic zone } & $\begin{array}{c}\text { UNESCO (1979) } \\
\text { P/PET } \\
\text { (Penman method) }\end{array}$ & $\begin{array}{c}\text { UNEP (1992) } \\
\text { P/PET } \\
\text { (Thornthwaite method) }\end{array}$ & \multicolumn{2}{c}{$\begin{array}{c}\text { Czech Republic } \\
\text { Ministry of Agriculture }\end{array}$} \\
\hline Hyper-arid & $<0.03$ & $<0.05$ & 1 (extra dry) & $<0.60$ \\
Arid & $0.03-0.20$ & $0.05-0.20$ & 2 (dry) & $0.61-1.11$ \\
Semi-arid & $0.20-0.50$ & $0.20-0.50$ & 3 (normal) & $1.12-1.61$ \\
Sub-humid & $0.50-0.75$ & $0.50-0.65$ & 4 (wet) & $1.62-2.11$ \\
Humid & $>0.75$ & $>0.65$ & 5 (extra wet) & $>2.12$ \\
\hline
\end{tabular}

and 6. The used classifying scale is proposed by the Ministry of Agriculture (Tab. I). And in the Tab. I is also mentioned the classifying scale proposed by the United Nations Environment Programme (UNEP, 1992), and also the previous classification that was proposed by the United Nations Educational, Scientific and Cultural Organization (UNESCO,1979) is presented (Nastos et al., 2013).

In the evaluation we compared the results in particular decades according to classification scale of the Czech Republic (Ministry of Agriculture) and classification limits of UNESCO and UNEP (Nastos et al, 2013). The classification limits of the Czech Republic are less restrictive due to different geographical conditions of the country but even though, some parts of the Czech Republic are comparable with classification limits by Nastos et al. (2013). During the decade 1961-1970, almost the whole area of the Czech Republic is classified as "wet" with AI values ranging above 0.60, except the small part of the south Moravia (surroundings of Dyje river and Znojmo city-Podyjí national park), which are classified as "sub-humid" with AI value below 0.60. Over the next years, other areas of the south Moravia (e.g. Dyjsko-svratecký ravine, Valticko-lednický area, surroundings of Brno city), and also Prague city and Pooohří river basin shifted gradually to "sub humid" climate zone. Especially, during the pre-last decade of the study period 1991-2000.

Nastos et al. (2013) analyzed AI in Greece within the examined period 1951-2000 and they also found progressive shift from the "humid" class, which characterized the wider area of Greece, towards the „sub-humid“ and „semi-arid“ classes appeared in some parts of Greece, mainly in eastern part of Greece.

Potop et al. (2011) evaluated drought occurrences at various time scales in the lowland regions and found out interesting decadal distribution of the number of drought events. Spring droughts were non-existent in the decades 1961-1970 and 1981-1990, spring droughts gained in persistence during decades 1991-2000 and 2001-2010. An interesting decadal distribution of a number of drought events was found during the autumn season. The periods 1941-1950 (the extreme and persistent drought of 1947) and 2001-2010 (note the drought of 2003 and 2006) were ranked as having a large number of long severe drought events. In our results were found AI higher (it means less dry) in period 2001-2010 than in 1991-2000, this may be due to that we have analyzed the year as a whole not as particular seasons.

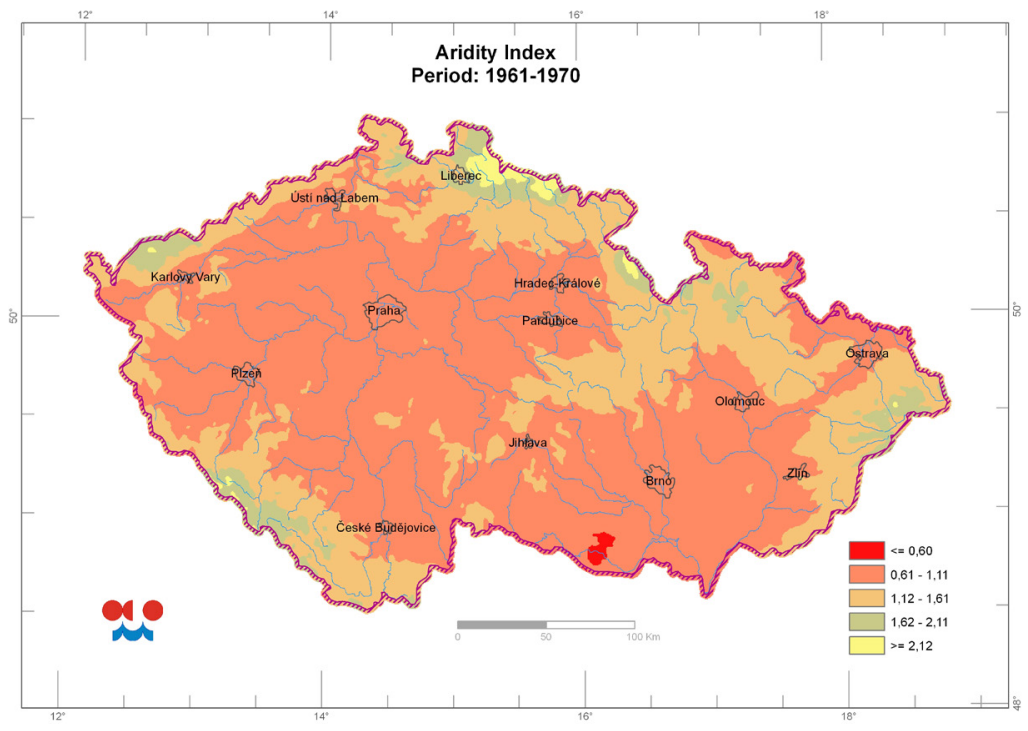

2: Spatial distribution of the Aridity Index in period 1961-1970, based on stations' data. 


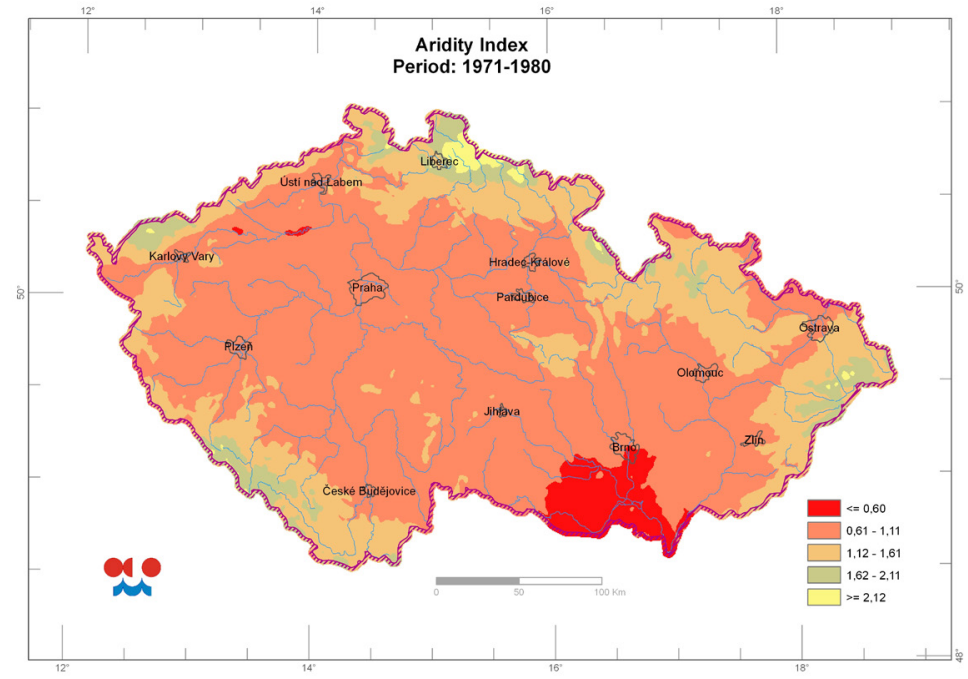

3: Spatial distribution of the Aridity Index in period 1971-1980, based on stations' data.

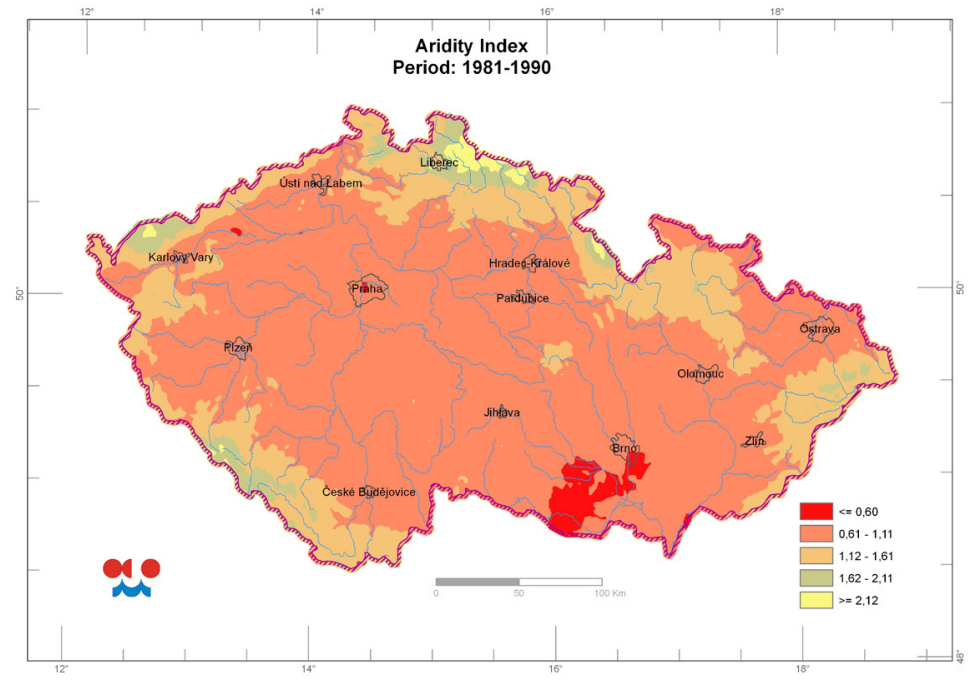

4: Spatial distribution of the Aridity Index in period 1981-1990, based on stations' data.

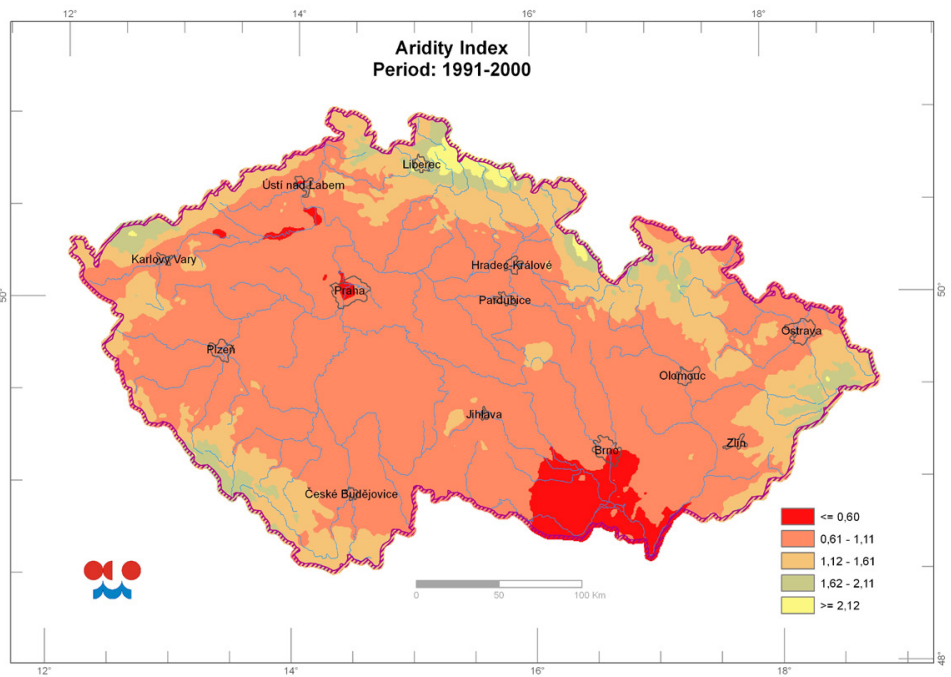

5: Spatial distribution of the Aridity Index in period 1991-2000, based on stations' data. 


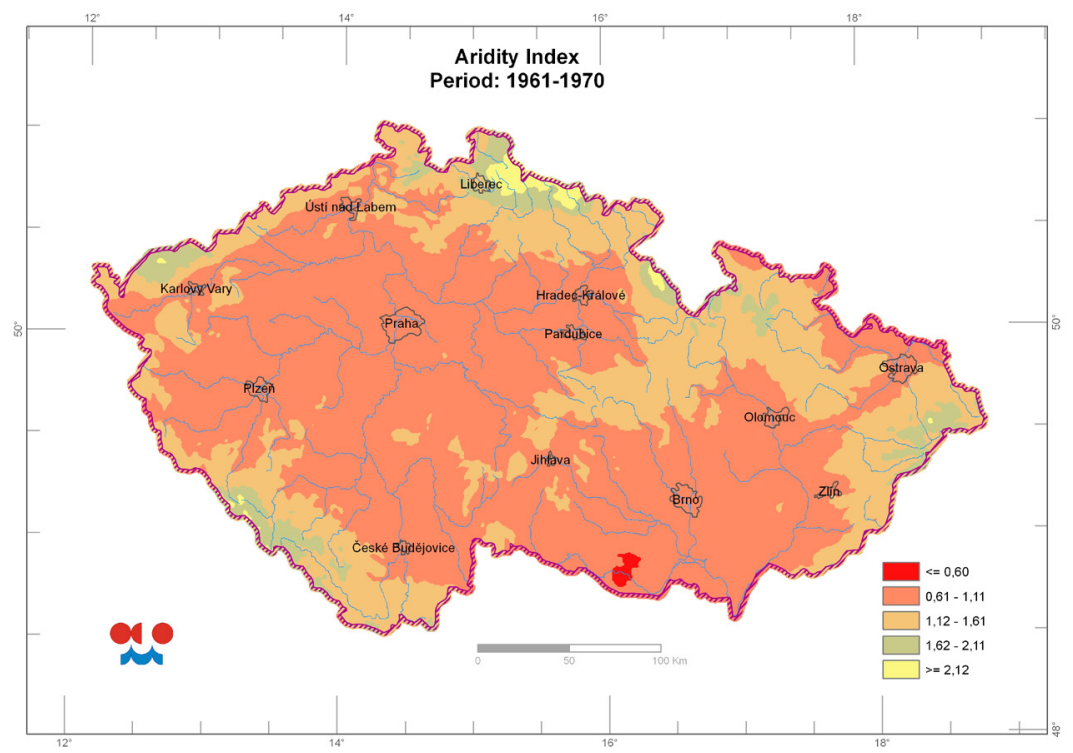

6: Fig. 6 Spatial distribution of the Aridity Index in period 2001-2010, based on stations' data

Trnka et al. (2007) evaluated relationship between detrended district yields of spring barley (1961-2000) and meteorological drought was assessed by Palmer Z-index. They found as the most drought-sensitive cluster included five districts in the South East of the country (as it is shown in our results of AI, mainly in period 1991-2000). On the other hand, the districts in Northern Moravia and Silesia belong among the least sensitive to agricultural drought.

Basic statistical characteristics of Aridity Index within period 1961-2015 are given in Tab. II. The average 1981-2010 is slightly lower than 1961-1990, but upper quartile, median and lower quartile are more important lower, while standard deviation, variation coefficient and variation range are higher.

Fig. 7 and 8 illustrate the comparison of AI and Moisture balance evaluation in various regions within different periods (1961-1990, 1981-2010, 1961-2010).

The lowest values of AI within the examined period (1961-2010) are in Jihomoravský region, Prague city and Středočeský region, on the other side, the highest values of AI (more then 1.4) shows Liberecký region. In addition, the Jihomoravský, Středočeský and also Ústecký regions and Vysočina region including Prague city area have negative moisture balance (Fig. 8). Pardubický and Olomoucký regions have negative moisture balance only in period 1981-2010. The period 1981-2010 can be described as the least favorable, e.g. the negative moisture balance in Jihomoravský region was $-225.3 \mathrm{~mm}$ and in Středočeský region it was $-131.5 \mathrm{~mm}$. Comparing with period 1961-1960, the increase in the negative moisture balance was higher than $20 \mathrm{~mm}$ in both regions, and was even higher in Středočeský region. Tab. 3 depicts basic statistical characteristics of moisture balance of the whole republic with high declaring ability. The moisture balance is more understandable parameter than AI.The difference between period 1961-1990 and 1981-2010 is $13.3 \mathrm{~mm}$ on average. The differences between maximum and minimum values are higher in period 1981-2010 in comparison to 1961-1990.

II: Basic statistical characteristics of Aridity Index

\begin{tabular}{|c|c|c|c|}
\hline & $1961-1990$ & $1981-2010$ & 1961-2015 \\
\hline Average & 1.10 & 1.07 & 1.08 \\
\hline Minimum & $\begin{array}{c}0.34 \\
\text { (1978, Kuchařovice station) }\end{array}$ & $\begin{array}{c}0.26 \\
\text { (2003, Prague-Karlov station) }\end{array}$ & $\begin{array}{c}0.26 \\
\text { (2003, Prague-Karlov station) }\end{array}$ \\
\hline Upper quartile & 0.79 & 0.75 & 0.77 \\
\hline Median & 1.00 & 0.95 & 0.97 \\
\hline Lower quartile & 1.27 & 1.22 & 1.25 \\
\hline Maximum & 4.21 (1981, Desná station) & 4.44 (2010, Lysá hora station) & 4.44 (2010, Lysá hora station) \\
\hline Standard deviation & 0.48 & 0.49 & 0.49 \\
\hline Variation coefficient & 0.44 & 0.46 & 0.45 \\
\hline Variation range & 3.87 & 4.18 & 4.18 \\
\hline
\end{tabular}




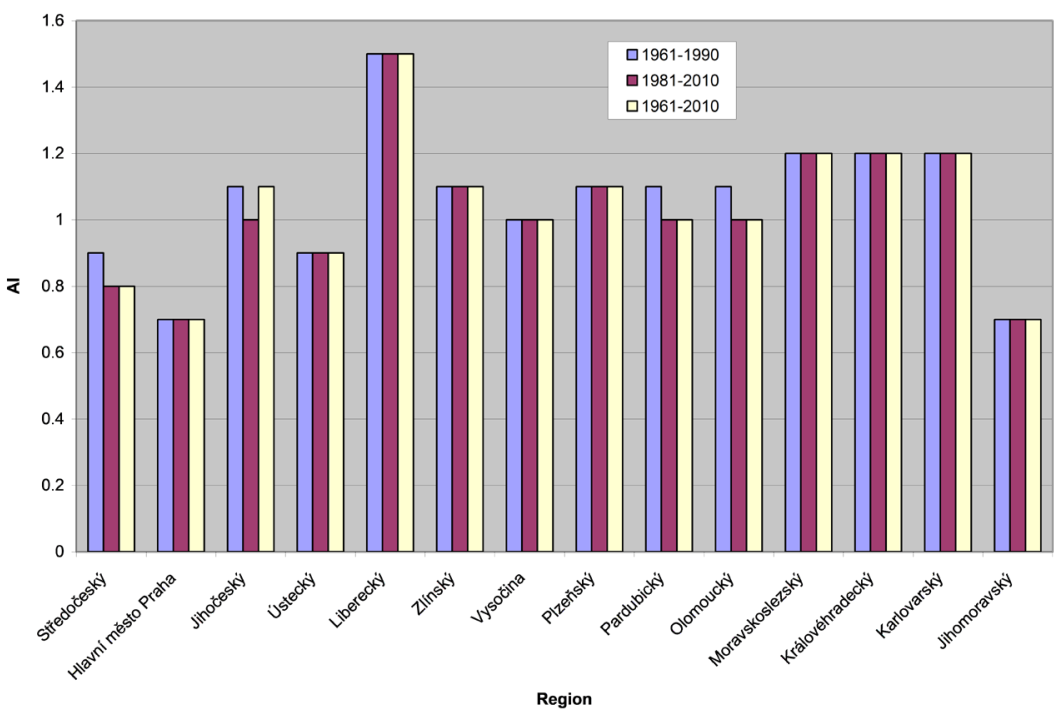

7: Evaluation of AI in various regions of the Czech Republic

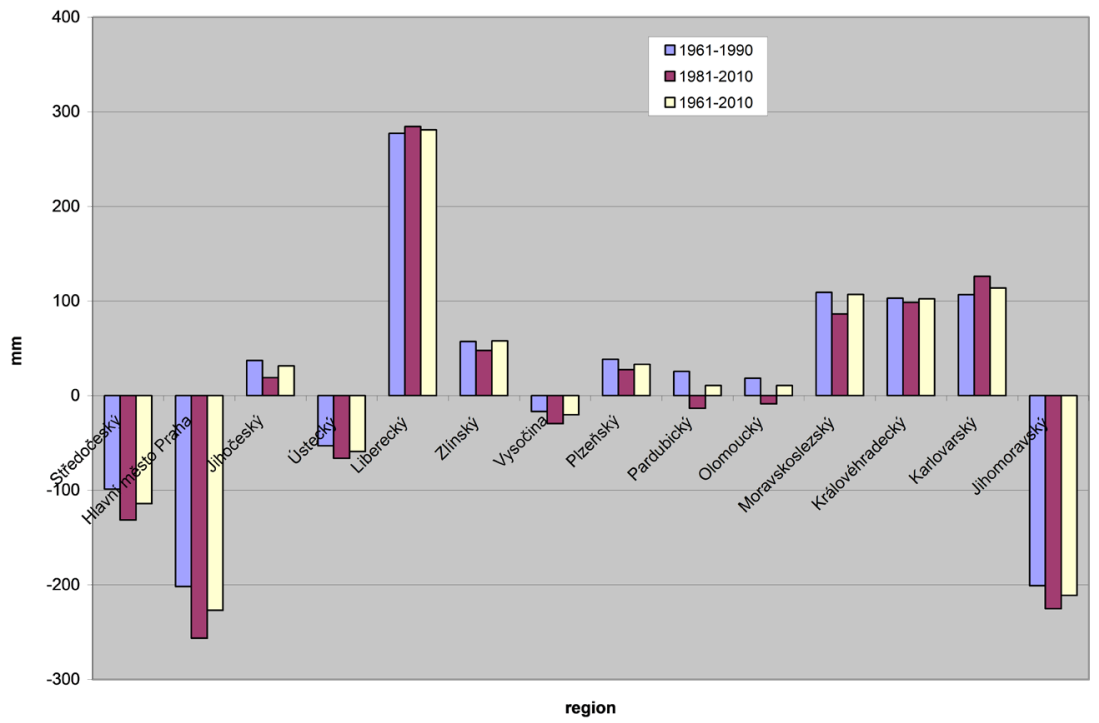

8: Evaluation of moisture balance in various regions of the $\mathrm{Czech}$ Republic

III: Basic statistical characteristics of moisture balance

\begin{tabular}{|c|c|c|c|}
\hline & $1961-1990$ & $1981-2010$ & 1961-2015 \\
\hline Average & $38.6 \mathrm{~mm}$ & $25.3 \mathrm{~mm}$ & $34.9 \mathrm{~mm}$ \\
\hline Minimum & $\begin{array}{c}-640.4 \mathrm{~mm} \\
\text { (1983, Kuchařovice station) }\end{array}$ & $\begin{array}{c}-723.5 \text { (2003, Prague-Karlov } \\
\text { station) }\end{array}$ & $\begin{array}{c}-723.5 \\
\text { (2003, Prague-Karlov station) }\end{array}$ \\
\hline Upper quartile & -140.4 & -168.9 & -150.5 \\
\hline Median & 0.6 & -21.5 & -5.1 \\
\hline Lower quartile & $161.3 \mathrm{~mm}$ & $148.6 \mathrm{~mm}$ & $156.8 \mathrm{~mm}$ \\
\hline Maximum & $\begin{array}{c}1482.9 \text { mm (1981, Desná } \\
\text { station) }\end{array}$ & $\begin{array}{c}1650.0 \\
\text { (2010, Lysá hora station) }\end{array}$ & $\begin{array}{c}1650.0 \\
\text { (2010, Lysá hora station) }\end{array}$ \\
\hline Standard deviation & $272.4 \mathrm{~mm}$ & $293.1 \mathrm{~mm}$ & $284.2 \mathrm{~mm}$ \\
\hline Variation coefficient & 7.1 & 11.6 & 8.1 \\
\hline Variation range & 2123.4 & 2290.5 & 2373.6 \\
\hline
\end{tabular}




\section{CONCLUSIONS}

This paper examines the spatial and temporal assessment of the Aridity Index (AI) and moisture balance within the wider area of the Czech Republic for the period 1961-2015 and in particular decades as well. The results of the analysis showed, that during the decade 1961-1970, almost the whole area of the Czech Republic is classified as "wet" with AI values ranging above 0.60. But over the next years (1971-2015), some areas of the south Moravia and also Prague city and Poohř́ river basin shifted gradually to "sub-humid" climate zone with $\mathrm{AI}<=0.60$. Especially, during the pre-last decade of the study period 1991-2000. Aridity Index is closely connected with moisture balance. In comparison of particular regions, the worst situation in water supply is in Jihomoravský and Středočeský region including Prague city area, and also Ústecký and Vysočina regions show negative moisture balance. Liberecký region has the „best" results in AI and moisture balance. It is important to evaluate moisture balance and AI also in the future to get results for the longest period.

\section{Acknowledgements}

This work was supported by the Ministry of Education, Youth and Sports of CR within the National Sustainability Program I (NPU I), grant number LO1415 and by the projects funded by National Agency for Agricultural Research "Crop modelling as a tool for increasing the production potential and food security of the Czech Republic under Climate Change" (QJ1310123).

\section{REFERENCES}

ALLEN, R. G., PEREIRA, L. S., RAES, D. and SMITH, M. 1998. Crop evapotranspiration. Guidelines for computing crop water requirements. Irrigation and Drainage Paper 56. Rome. Italy: Food and Agric. Organization of the United Nations.

ARORA, V. K. 2002. The use of the aridity index to assess climate change effect on annual runoff. Journal of Hydrology, 265: 164-177.

BRÄZDIL, R., DOBROVOLNÝ , P., ELLEDER, L., KAKOS, V., KOTYZA, O., KVĚTOŇ, V., MACKOVÁ, J., MÜLLER, M., ŠTEKL, J., TOLASZ, R. and VALÁŠEK, H. 2005. Historical and Recent Floods in the Czech Republic. Brno, Prague: Masaryk University, Czech Hydrometeorological Institute.

BRÁZDIL, R., BŘEZINA, L., DOBROVOLNÝ, P., DUBROVSKÝ, M., HALAŠOVÁ , O., HOSTÝNEK, J., CHROMÁ, K., JANDERKOVÁ, J., KALÁB, Z., KEPRTOVÁ, K., KIRCHNER, K., KOTYZA, O., KREJČÍ, O., KUNC, J., LACINA, J., LEPKA, Z., LÉTAL, A., MACKOVÁ, J., MÁČKA, Z., MULÍČEK, O., ROŠTÍNSKÝ, P., ŘEHÁNEK, T., SEIDENGLANZ, D., SEMERÁDOVÁ, D., SOKOL, Z., SOUKALOVA' ', E., ŠTEKL, J., TRNKA, M., VALÁŠEK, H., VĚŽNÍK, A., VOŽENÍLEK, V. and ŽALUD, Z. 2007. Selected natural extremes and their impacts in Moravia and Silesia. Brno, Praha, Ostrava: Masaryk University, Czech Hydrometerological Institute, Institute of Geonics, Academy of Science of the Czech Republic.

BRÁZDIL, M. et al. 2015. Sucho v Českých zemích: minulost, současnost, budoucnost. In: Historie počasía podnebív českých zemích, svazek XI. Brno: Centrum výzkumu globální změny Akademie věd České republiky, v.v.i.

MOŽNÝ, M., 2004. Definition and intensity of drought on the territory of the Czech Republic in the period 1891-2003. Praha: ČHMÚ.

NASTOS, P. T., POLITI, N. and KAPSOMENAKIS, J. 2013. Spatial and temporal variability of the Aridity Index in Greece. Atmospheric Research, 119: 140-152.

NIEMEYER, S. 2008. New drought indices. In: LÓPEZ-FRANCOS, A. (Ed.). Drought management: scientific and technological innovations. Zaragoza: CIHEAM, pp. 267-274.

POTOP, V., MOŽNÝ, M. and SOUKUP, J. 2011. Drought evolution at various time scales in the lowland regions and their impact on vegetable crops in the Czech Republic. Agricultural and Forest Meteorology, 156, 121-133.

ROSSI, G., BENEDINI, M., TSAKIRIS, G. and GIAKOUMAKIS, S., 1992. On regional drought estimation and analysis. Water Resour. Manag., 6(4): 249-277.

ŠTĚPĂNEK, P. 2010a AnClim - software for time series analysis. Brno: Department of Geography, Faculty of Natural Science, MU. Available at: http://www.climahom.eu/AnClim.html

ŠTĚPÁNEK, P. 2010b. ProClimDB - software for processing climatological datasets. Brno: CHMI, regional office Brno Available at: http://www.climahom.eu/ProcData.html

TRNKA, M., HLAVINKA, P., SEMERÁDOVÁ, D., DOBROVSKÝ, M., ŽALUD, Z. and MOŽNÝ, M. 2007. Agricultural drought and spring barley yields in the Czech Republic. Plant Soil Environ., 53(7): 306-316.

UNEP. 1992. World Atlas of Desertification. London: Edward Arnold.

UNESCO. 1979. Map of the world distribution of arid regions. Explanatory Note. MAB Technical Notes 7. Man and Biosphere (MAB). UNESCO:

WILHITE, D. A. (Ed.). 2000. Drought: A Global Assessment. London: Routledge Publishers. 
Contact information

Lenka Bartošová: bartolen@gmail.com 